\title{
Endoplasmic Reticulum Stress Impairs Insulin Signaling through Mitochondrial Damage in SH-SY5Y Cells
}

\author{
Hyun-Jung Koo Ying Piao Youngmi Kim Pak \\ Neurodegeneration Control Research Center, Department of Neuroscience, Department of Physiology, \\ College of Medicine, Kyung Hee University, Seoul, Korea
}

\section{Key Words}

Neurodegeneration · Thapsigargin · Mitochondria · Stress •

Signal transduction $\cdot$ Insulin

\begin{abstract}
Endoplasmic reticulum (ER) and mitochondrial stress are considered causal factors that induce neurodegenerative diseases. However, the relationship between these stresses remains poorly understood. To investigate the molecular mechanism underlying crosstalk between the ER and mitochondria in neurodegeneration, we treated SH-SY5Y human neuroblastoma cells with thapsigargin and tunicamycin, two inducers of ER stress, and atrazine, a promoter of mitochondrial stress. Each pharmacological agent caused mitochondrial dysfunction, which was characterized by reduced intracellular ATP, mitochondrial membrane potential, and endogenous cellular respiration as well as an augmentation of oxidative stress. Oligonucleotide microarray analysis followed by semiquantitative RT-PCR validation assays revealed that thapsigargin and tunicamycin downregulated the expression of most mitochondria-related genes in a manner similar to that induced by atrazine. In contrast, atrazine did not alter the expression of markers of ER stress. Three-dimensional principal component analysis showed that the gene expression profile produced by atrazine treatment was
\end{abstract}

distinct from that generated by ER stress. However, all three agents impaired insulin receptor substrate-1 and Akt phosphorylation in the insulin signaling pathway. Ectopic overexpression of mitochondrial transcription factor A reversed the effects of thapsigargin on mitochondria and Akt signaling. We conclude that ER stress induces neuronal cell death through common perturbation of mitochondrial function and Akt signaling.

Copyright $\odot 2012$ S. Karger AG, Basel

\section{Introduction}

The endoplasmic reticulum (ER) is a multifunctional organelle responsible for protein folding and modification, lipid synthesis, $\mathrm{Ca}^{2+}$ homeostasis, and secretory protein trafficking in eukaryotic cells. A variety of pathophysiological insults induce stress in the ER by perturbing its normal function or structure. For instance, thapsigargin (Thap) disrupts intracellular $\mathrm{Ca}^{2+}$ homeostasis by inhibiting sarco/ER-associated $\mathrm{Ca}^{2+}$-ATPase (SERCA). Tunicamycin (Tuni) prevents proper protein folding by inhibiting $\mathrm{N}$-linked protein glycosylation $[1$,

Hyun-Jung Koo and Ying Piao contributed equally to the paper.

Youngmi Kim Pak, PhD

Neurodegeneration Control Research Center, Department of Physiology

College of Medicine, Kyung Hee University

Dongdaemoon-Gu Hoegi-Dong 1, Seoul 130-701 (Korea)

E-Mail karger@karger.ch Accessible online at:

www.karger.com www.karger.com/nsg 
2]. Both of these agents cause an accumulation of unfolded and misfolded proteins in the ER and trigger signaling pathways associated with the 'unfolded protein response' (UPR) [3].

The UPR arrests protein synthesis and removes any aberrant protein that has accumulated so that normal ER function can quickly be restored [4]. The UPR is coordinately regulated by three proximal sensors, inositol-requiring enzyme 1 (IRE-1), PKR-like endoplasmic reticulum kinase (PERK), and activating transcription factor 6 (ATF6), which are involved in the halting of translation, ER-associated degradation, and transcriptional upregulation of ER chaperone proteins such as glucose-regulated protein $78 \mathrm{kDa}$ (GRP78), respectively. Activation of IRE1 leads to cleavage and splicing of an intron within X-box binding protein-1 (XBP-1) to produce spliced XBP-1 (sXBP-1), a bZIP transcription factor that translocates to the nucleus and regulates the expression of genes involved in ER-associated degradation and molecular chaperones. The chaperone GRP78, also known as BiP, protects cells from toxicity due to misfolded proteins by blocking ER stress signals and maintaining the function and integrity of this organelle [5]. Based on these critical roles, GRP78 and sXBP-1 serve as ER stress markers. However, prolonged UPR activation or failure to attenuate ER stress can lead to apoptotic cell death and subsequent tissue dysfunction $[6,7]$. These outcomes have been linked to a wide range of age-associated degenerative diseases, including neurodegenerative disorders, cancer, diabetes and fatty liver disease $[8,9]$.

Another essential organelle is the mitochondrion, which participates in numerous metabolic reactions, provides the majority of the cellular energy via oxidative phosphorylation, and plays a key role in $\mathrm{Ca}^{2+}$ signaling, apoptosis and aging. Mitochondrial dysfunction has also been associated with a diverse range of diseases [10], many of which are also caused by ER stress. In particular, neurodegenerative diseases such as Alzheimer's disease (AD), Parkinson's disease (PD), and Huntington's disease (HD) exhibit features of mitochondrial damage [11] as well as accumulation and aggregation of misfolded proteins $[5,12,13]$. Aggregation of amyloid beta $(A \beta), \alpha-$ synuclein, and huntingtin deposits in the brain are hallmarks of $\mathrm{AD}, \mathrm{PD}$, and $\mathrm{HD}$, respectively. These deposits lead to UPR, which induces mitochondrial cytochrome c release and the initiation of neuronal cell death. However, $\mathrm{A} \beta, \alpha$-synuclein, and huntingtin are localized in mitochondria, where they may directly damage mitochondrial function. The ER and mitochondria are located adjacent to each other within the cell and modulate $\mathrm{Ca}^{2+}$ sig- naling together; therefore, it is likely that communication exists between these organelles [14]. In fact, several proteins at the ER-mitochondria interface have been reported to regulate $\mathrm{Ca}^{2+}$ signaling $[15,16]$. However, the molecular mechanism underlying communication between the ER and mitochondria has yet to be elucidated.

Insulin signaling regulates several functions in the brain, including glucose homeostasis, memory formation, and neuronal development [17]. Blockade of insulin signaling has been linked to AD and PD [18-20]. Insulin mediates its effects by inducing sequential phosphorylations of insulin receptor and insulin receptor substrate (IRS). IRS-1 possesses sites of tyrosine and serine phosphorylation that induce opposing effects on the insulin signaling pathway. In particular, tyrosine phosphorylation (Y632) stimulates phosphoinositide-dependent kinase and activation of its downstream effectors, PI3K and Akt [21]. Meanwhile, serine phosphorylation at position 307 or 794 regulates PI3K/Akt signaling negatively and contributes to the development of insulin resistance [22, 23]. Moreover, depending on the tissue, phosphorylation of Akt at T308 or S473 mediates cell survival or insulin anabolic functions such as glucose transport $[24,25]$ and lipogenesis [26, 27].

Although neurodegenerative diseases have been linked to insulin signaling, ER stress and mitochondrial dysfunction, the relationship between these facets has not been clearly demonstrated. In this study, we investigated the molecular crosstalk between ER stress and mitochondrial dysfunction in neuronal cells using microarray analysis. ER stress was induced in SH-SY5Y human neuroblastoma cells by treatment with Thap or Tuni, while mitochondrial stress was produced by treatment with atrazine (ATZ), a triazine-based herbicide. Previously, we have shown that ATZ inhibits mitochondrial oxidative phosphorylation (OXPHOS) at the Coenzyme Q site and induces mitochondrial dysfunction [28]. By comparing the effects of these three chemicals on mitochondrial function and insulin signaling, we demonstrated that two ER stressors induced neuronal cell apoptosis through impairment of both mitochondrial function and insulin signal transduction.

\section{Materials and Methods}

Cell Culture and Transient Transfection

SH-SY5Y human neuroblastoma cells were cultured in Dulbecco's modified Eagle medium (DMEM)/F12 supplemented with $10 \%$ fetal bovine serum (FBS), $100 \mathrm{U} / \mathrm{ml}$ penicillin, and 100 $\mu \mathrm{g} / \mathrm{ml}$ streptomycin at $37^{\circ} \mathrm{C} / 5 \% \mathrm{CO}_{2}$. The cells were cultured in 
60-mm or 96-well plates for $48 \mathrm{~h}$ followed by incubation in serumdeficient media (SFM, DMEM/F12 containing $0.5 \%$ FBS) for $16 \mathrm{~h}$. The cells were then treated with the control vehicle dimethyl sulfoxide (DMSO), thapsigargin (1-2 $\mu \mathrm{g} / \mathrm{ml}$, Sigma-Aldrich, St. Louis, Mo., USA), tunicamycin (1-2 $\mu \mathrm{g} / \mathrm{ml}$, Sigma-Aldrich), or atrazine (50-100 $\mu \mathrm{g} / \mathrm{ml}$, Dr. Ehrenstorfer GmbH, Augsberg, Germany) for $24 \mathrm{~h}$ before harvesting. Expression plasmids $(1 \mu \mathrm{g} / \mathrm{ml})$, pcDNA3.1-human TFAM (pTFAM) [29] or pcDNA3.1-NRF-1 (pNRF-1) [30] were transfected into 50\% confluent SH-SY5Y cells seeded onto 24-well plates using SuperFect ${ }^{\circledR}$ Transfection Reagent (Qiagen, Hilden, Germany). The pcDNA3.1 vector was used as a negative control in mock transfections. Transfected cells were maintained for $24 \mathrm{~h}$ in fresh complete media (CM, DMEM/F12 containing $10 \% \mathrm{FBS}$ ), cultured for another $16 \mathrm{~h}$ in SFM, and then treated with thapsigargin $(1 \mu \mathrm{g} / \mathrm{ml})$ for $24 \mathrm{~h}$ before use in assays examining mitochondrial function or Western blotting.

\section{Methyl Thiazol Tetrazolium Assay}

The methyl thiazol tetrazolium (MTT) assay measures mitochondrial dehydrogenase activity in live cells. SH-SY5Y cells $(2.5$ $\times 10^{4}$ cells/well) were plated onto 96-well plates in SFM and treated with Thap, Tuni or ATZ for $24 \mathrm{~h}$ and then further incubated with 3-(4,5 dimethylthiazol-2-yl)-2,5-diphenyl-tetrazolium bromide (MTT, Sigma-Aldrich) solution $(0.2 \mathrm{mg} / \mathrm{ml}$ MTT in PBS) for $4 \mathrm{~h}$. The MTT formazan precipitates formed by the live cells were dissolved in $100 \mu \mathrm{l}$ of $0.04 \mathrm{~N} \mathrm{HCl} /$ isopropanol. The absorbance at $540 \mathrm{~nm}$ was measured using an enzyme-linked immunosorbent assay (ELISA) microplate reader (Molecular Devices, Sunnyvale, Calif., USA) [31].

\section{Calcein Viability Assay}

Cells $\left(2.5 \times 10^{4}\right.$ cells/well $)$ were cultured in black 96-well plates in phenol red-free CM for $24 \mathrm{~h}$. The cells were then incubated for $16 \mathrm{~h}$ in phenol red-free SFM, after which they were incubated with $0.5 \mu \mathrm{M}$ Calcein AM (Molecular Probes, Eugene, Oreg., USA) in DMSO at $37^{\circ} \mathrm{C}$ for $1 \mathrm{~h}$. The media was replaced with $100 \mu \mathrm{l}$ DPBS and the fluorescence intensity was measured using a fluorescence plate reader (Victor, Perkin Elmer, Waltham, Mass., USA) at $485 \mathrm{~nm}$ (excitation) and $535 \mathrm{~nm}$ (emission). Fluorescence intensity was normalized by protein concentration.

\section{Apoptosis Assays}

Apoptotic cell death was measured using the Cell Death Detection ELISA kit (Roche, Basel, Switzerland) according to the manufacturer's instructions. This kit provides a photometric enzyme immunoassay for in vitro determination of cytoplasmic histone-associated DNA fragments after cell death induction.

To assess DNA fragmentation of cellular genomic DNA, cells cultured in $60-\mathrm{mm}$ dishes were treated with Thap, Tuni or ATZ for $24 \mathrm{~h}$ and harvested with lysis buffer $(10 \mathrm{~mm}$ Tris- $\mathrm{HCl}, \mathrm{pH} 7.8$, $5 \mathrm{mM}$ EDTA, $\mathrm{pH}$ 8.0, 0.5\% w/v SDS, and $50 \mu \mathrm{g} / \mathrm{ml}$ proteinase $\mathrm{K}$ ) overnight. Genomic DNA was extracted as described previously [31], analyzed on $2 \%$ agarose gels, and stained with SYBR ${ }^{\circledR}$ Green I nucleic acid stain (Molecular Probes).

\section{Intracellular ATP Content}

Intracellular ATP content was measured using the luciferinluciferase reaction with ATP bioluminescent somatic cell assay kit (Sigma-Aldrich) according to the manufacturer's instructions. Briefly, $100 \mu$ l of cell lysate was mixed with $100 \mu$ l of the luciferin- luciferase reaction buffer and incubated at $20^{\circ} \mathrm{C}$ for $10 \mathrm{~min}$. Luminescence was measured with an LB 9501 Lumat luminometer (Berthold, Germany). Background luminescence in control wells containing medium without cells was subtracted from experimental samples. The amount of ATP content was normalized to protein concentration. All data are presented as a percent of control after background subtraction.

\section{Endogenous Cellular Oxygen Consumption Rate}

Endogenous cellular respiration was measured using the Oxygraph-2K (Oroboros, Innsbruck, Austria) as described previously [32]. Measurements were performed using $6 \times 10^{6}$ cells. After a basal (coupled) respiration rate was obtained, uncoupled respiration was measured by adding $1 \mu \mathrm{M}$ carbonyl cyanide $p$-trifluoromethoxyphenylhydrazone (FCCP). To measure the state 2 (resting complex I-supported respiration) and state 3 (maximal mitochondrial respiration) respiration rates, cells $\left(6 \times 10^{6}\right)$ in respiration media were permeabilized with $10 \mu \mathrm{g} / \mathrm{ml}$ digitonin in the Oxygraph-2K chamber. State 2 (-ADP) and state 3 oxygen consumption rate (OCR) (+ADP) were determined by serial addition of substrates (10 mM pyruvate and $4 \mathrm{~mm}$ malate) and $1.5 \mathrm{~mm}$ ADP, respectively. The OCR was normalized by protein concentration ( $\mathrm{pmol} / \mathrm{s} / \mathrm{mg}$ protein) and expressed as a percentage of control.

\section{Assays for Mitochondrial Membrane Potential and Reactive}

Oxygen Species

Mitochondrial membrane potential was measured using tetramethylrhodamine ethylester (TMRE, Molecular Probes). Cells cultured in black 96 -well plates were incubated at $37^{\circ} \mathrm{C}$ for $30 \mathrm{~min}$ with $200 \mathrm{nM}$ TMRE and $0.5 \mu \mathrm{M}$ Hoechst 33342 in phenol red-free SFM. Similarly, reactive oxygen species (ROS) generation was measured using 5,6-chloromethyl-2',7'-dichlorodihydrofluorescein diacetate, acetyl ester (CM- $\mathrm{H}_{2} \mathrm{DCFDA}$, Molecular Probes). The cells were incubated with $1 \mu \mathrm{M} \mathrm{CM}-\mathrm{H}_{2}$ DCFDA and $0.5 \mu \mathrm{M}$ Hoechst 33342 at $37^{\circ} \mathrm{C}$ for $1 \mathrm{~h}$. The fluorescence intensities at $550 / 580 \mathrm{~nm}$ for TMRE or 485/535 $\mathrm{nm}$ for dichlorofluorescein diacetate (DCF-DA) were normalized by Hoechst intensity at $355 / 460 \mathrm{~nm}$.

\section{Detection of Protein Oxidation}

Immunodetection of oxidized proteins was performed using the OxyBlot protein oxidation detection kit (Chemicon International, Temecula, Calif., USA) [33]. The 2,4-dinitrophenylhydrazine (DNPH)-treated samples were mixed with an equal volume of sodium dodecyl sulfate sample buffer and resolved by $10 \%$ sodium dodecyl sulfate polyacrylamide gel electrophoresis (SDSPAGE). The DNPH-derivatized carbonyl proteins were transferred onto polyvinylidene fluoride membranes and detected using an anti-DNPH antibody and enhanced chemiluminescence similar to Western blotting. To confirm equal loading of proteins, the membrane was probed by Western blot using an anti- $\beta$-actin antibody (1:10,000, Sigma).

\section{RNA Isolation and Semiquantitative RT-PCR}

Total RNA was extracted using Trizol reagent (Invitrogen, Carlsbad, Calif., USA) and then subjected to microarray analysis and semiquantitative RT-PCR. The semiquantitative RT-PCR was performed at cycles the PCR products did not reach saturation levels, as previously described [32]. The mitochondria-related genes include the genes for 13 mitochondrial DNA (mtDNA)-en- 
Table 1. Primers used for semiquantitative RT-PCR

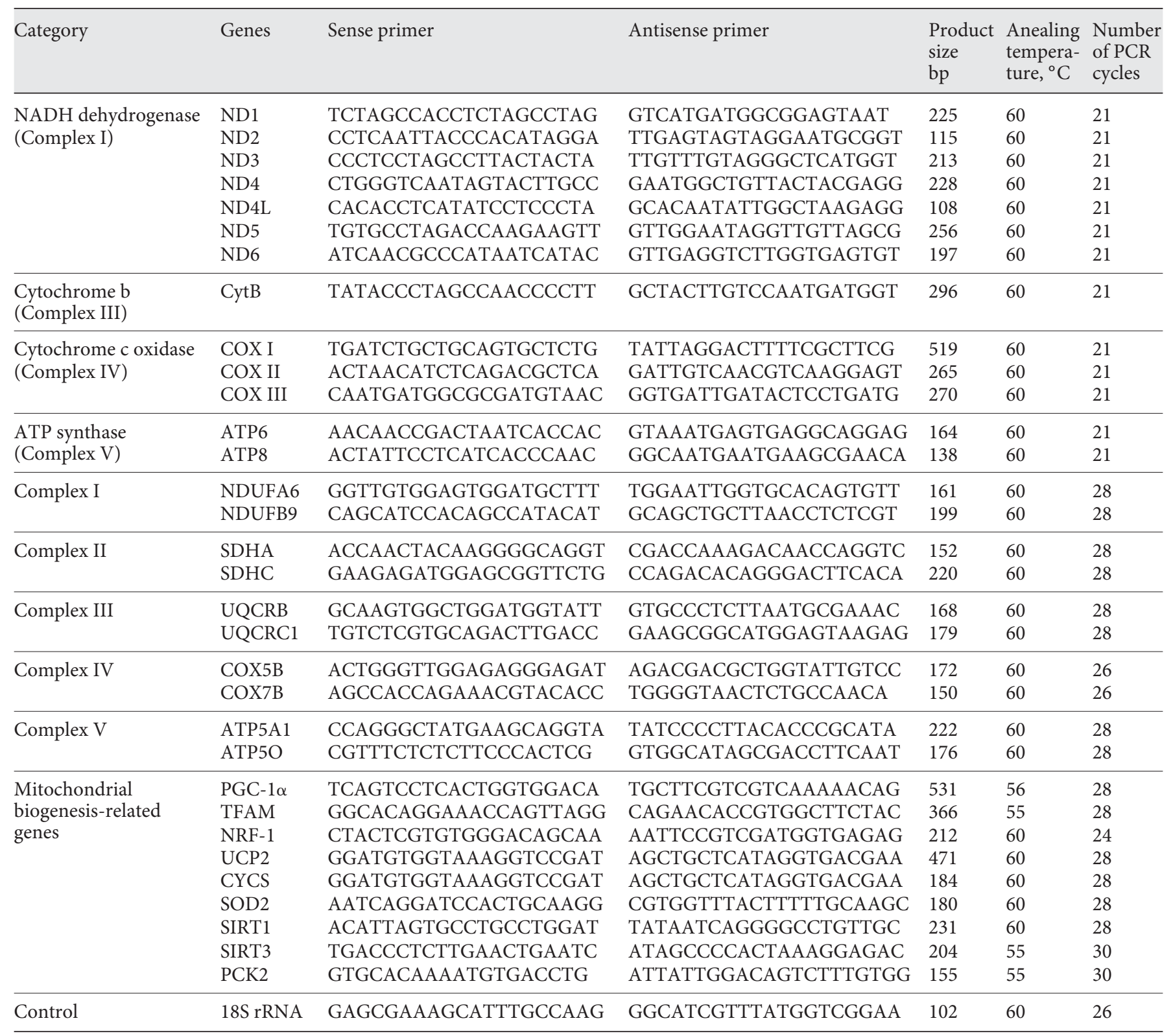

NDUFA6 = NADH dehydrogenase-1-alpha subcomplex subunit 6; NDUFB9 = NADH dehydrogenase-1-beta subcomplex 9; SDHA = succinate dehydrogenase complex subunit $\mathrm{A} ; \mathrm{SDHC}=$ succinate dehydrogenase complex subunit C; UQCRB = ubiquinol-cytochrome $\mathrm{c}$ reductase binding protein; $\mathrm{UQCRC1}=$ ubiquinol-cytochrome $\mathrm{c}$ reductase core protein $\mathrm{I}$; $\mathrm{COX} 5 \mathrm{~B}=$ cytochrome $\mathrm{c}$ oxidase subunit $\mathrm{Vb}$; $\mathrm{COX} 7 \mathrm{~B}=$ cytochrome $\mathrm{c}$ oxidase subunit VIIb; ATP5A1 = ATP synthase mitochondrial F1 complex alpha subunit 1; ATP5O = ATP synthase mitochondrial F1 complex O subunit.

coded subunits, nDNA-encoded OXPHOS subunits and mitochondrial biogenesis controlling proteins. The general PCR conditions were $10 \mathrm{~min}$ at $95^{\circ} \mathrm{C}, 30$ cycles of $30 \mathrm{~s}$ at $95^{\circ} \mathrm{C}$ and $30 \mathrm{~s}$ at $60^{\circ} \mathrm{C}$ (annealing temperature), and $30 \mathrm{~s}$ at $72^{\circ} \mathrm{C}$. The PCR products were analyzed on $1.2 \%$ agarose gel and quantified by densitometry. The mRNA levels were normalized to that of $18 \mathrm{~S}$ rRNA. RT-PCR primer sequences are provided in table 1.

\section{Microarray Analysis}

Microarray analysis was performed in triplicate using the Illumina Sentrix HumanRef-8 Expression BeadChip (24K) according to the Illumina Bead Array Technical Manual. Briefly, cDNA was synthesized from $500 \mathrm{ng}$ total RNA, and then an amplification/labeling step (in vitro transcription) using the Illumina ${ }^{\circledR}$ TotalPrep RNA amplification kit (Ambion, Inc., Austin, Tex., USA) 
Fig. 1. Stress-induced apoptosis in human SH-SY5Y neuroblastoma cells. SH-SY5Y cells cultured in serum-free media were treated as indicated for $24 \mathrm{~h} \mathrm{(a)} \mathrm{or} \mathrm{treated}$ with DMSO alone (CTL), Thap $(1 \mu \mathrm{g} / \mathrm{ml})$, Tuni $(2 \mu \mathrm{g} / \mathrm{ml})$, or ATZ $(100 \mu \mathrm{g} / \mathrm{ml})$ for $24 \mathrm{~h}$ (b-d). The harvested cells were assayed for MTT (a), calcein (b), DNA fragmentation (c), or apoptosis (d). Bar graphs are expressed as a percentage of CTL and represent the mean $\pm \mathrm{SE}(\mathrm{n}=6) .{ }^{* *} \mathrm{p}<$ 0.01 vs. CTL.

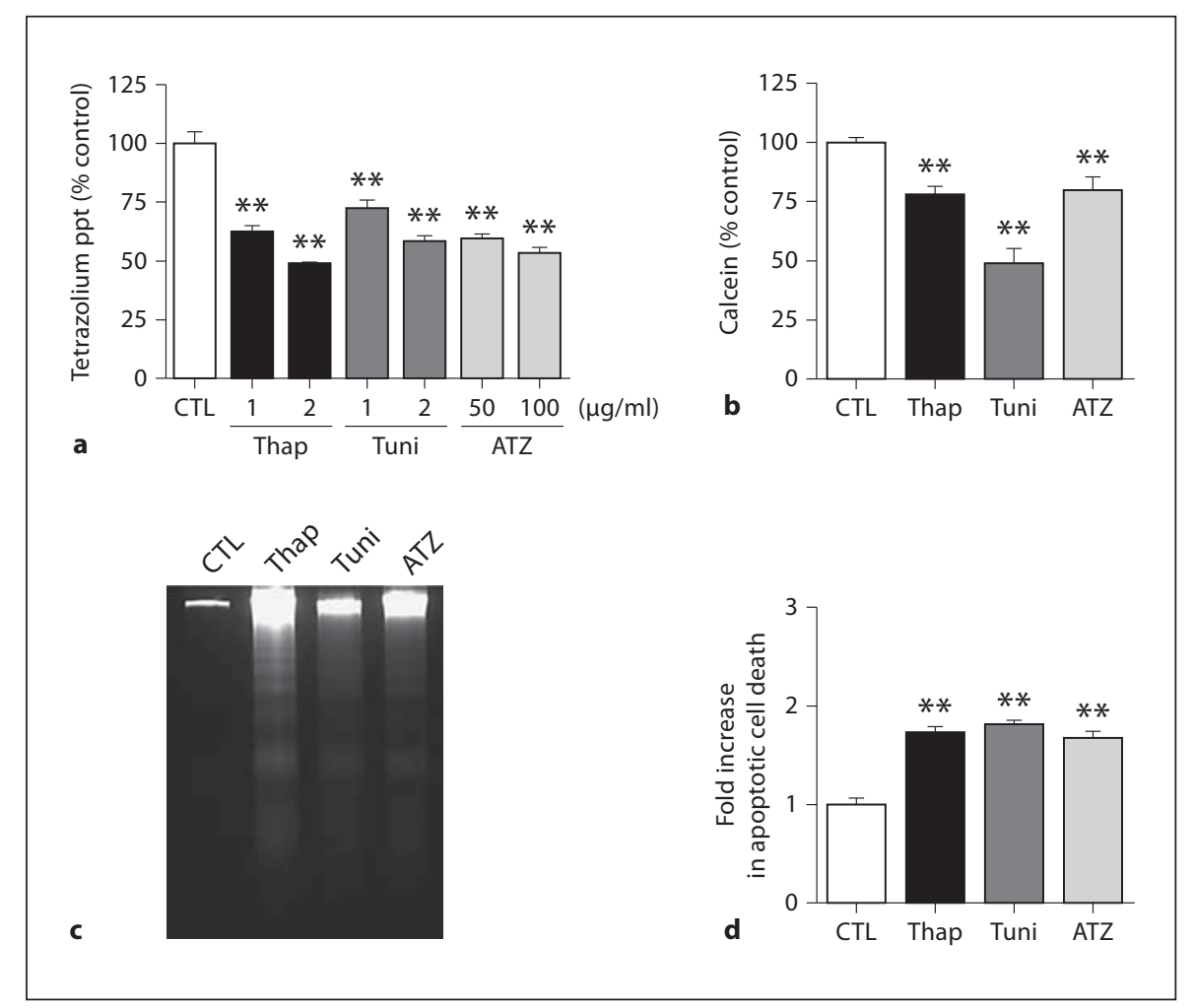

was performed to synthesize biotin-labeled cRNA. The cRNA sample (750 ng) was hybridized to the BeadChip and stained with streptavidin-Cy3. The chips were dried and scanned using the BeadArray reader. Raw scanned data were subjected to logarithmic transformation ( $\log _{2}$ ratios of fluorescence intensities) and quantile normalization using the Avadis 4.3 software (Strand Life Sciences, San Francisco, Calif., USA). Statistical significance was calculated using Benjamini-Hochberg false discovery rate multiple-testing correction. Data visualization, clustering, differential analysis and three-dimensional principal component analysis (3D-PCA) were also performed with Avadis 4.3 software. The Panther classification system (http://www.pantherdb.org) and Ingenuity Pathway Analysis software (Ingenuity Systems, http://www. ingenuity.com) were used for gene ontology and pathway analysis.

All microarray data reported in this study are described in accordance with MIAME guidelines and have been deposited in the National Center for Biotechnology Information Gene Expression Omnibus (GEO, http://www.ncbi.nlm.nih.gov/geo/) public repository. The data are accessible through the GEO accession number GSE24500.

\section{Western Blot Analysis}

SH-SY5Y cells were treated with Thap, Tuni or ATZ for $24 \mathrm{~h}$ and then stimulated with and without insulin/IGF as indicated. Protein extracts $(30 \mu \mathrm{g})$ were prepared in PRO-PREP lysis buffer (10 mM HEPES, pH 7.9, $10 \mathrm{mM} \mathrm{KCl,} 2 \mathrm{mM} \mathrm{MgCl}_{2}, 0.5 \mathrm{~mm}$ dithiothreitol, $1 \mathrm{mM}$ phenylmethylsulfonyl fluoride, $5 \mu \mathrm{g} / \mathrm{ml}$ aprotinin, $5 \mu \mathrm{g} / \mathrm{ml}$ pepstatin A, $5 \mu \mathrm{g} / \mathrm{ml}$ leupeptin, and $1 \%$ Triton X-100; iNtRON Biotech, Sungnam, Korea), resolved on 12\% SDS-PAGE gels, and analyzed by Western blot and enhanced chemiluminescence (ECL, Amersham Bioscience, Piscataway, N.J., USA). Primary antibodies against pIRS-1(Y632), pIRS-1(S307), IRS-1, Akt1, pAkt(T308), pAkt(S473), AMPK, and pAMPK(T172) were purchased from Cell Signaling Technology (Beverly, Mass., USA). Anti-human TFAM antibody was generated in our laboratory as described previously [34]. Equivalent protein loading was verified by probing with anti- $\beta$-actin or $\alpha$-tubulin antibody (SigmaAldrich).

\section{Statistical Analysis}

Data shown represent the mean \pm SE. Statistical significance was evaluated using the Student's t test or one-way ANOVA. p < 0.05 was considered significant.

\section{Results}

\section{ER and Mitochondrial Stress-Induced Apoptosis in Human Neuroblastoma Cells}

First, we measured the cell viability in SH-SY5Y cells treated for $24 \mathrm{~h}$ with Thap (1-2 $\mu \mathrm{g} / \mathrm{ml})$, Tuni (1-2 $\mu \mathrm{g} / \mathrm{ml})$, ATZ (50-100 $\mu \mathrm{g} / \mathrm{ml})$, or DMSO alone (CTL) using the MTT and calcein assays. All three agents reduced active mitochondria-dependent trizolium precipitation nearly $50 \%$ in a dose-dependent manner ( $p<0.01$ vs. CTL) 

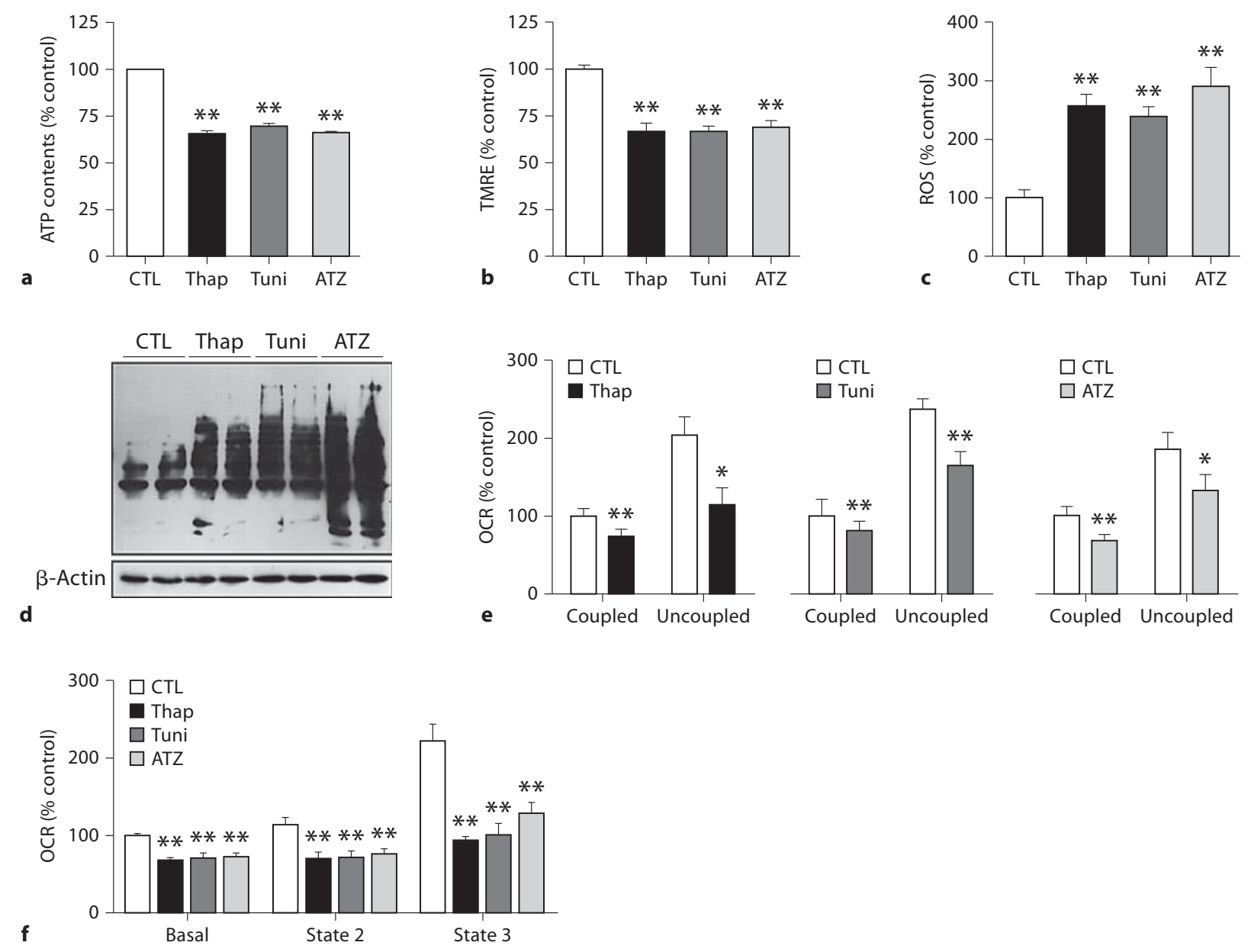

Fig. 2. ER stress-induced mitochondrial dysfunction. SH-SY5Y cells cultured in serum-free media were treated with DMSO alone (CTL), Thap $(1 \mu \mathrm{g} / \mathrm{ml})$, Tuni $(2 \mu \mathrm{g} / \mathrm{ml})$, or ATZ $(100 \mu \mathrm{g} / \mathrm{ml})$ for $24 \mathrm{~h}$. The harvested cells were analyzed for intracellular ATP content (a), TMRE to measure the mitochondrial membrane poten- tial $\Delta \psi_{\mathrm{m}}$ (b), DCF-DA for ROS (c), carbonylated protein (d), uncoupled and FCCP-coupled (+FCCP) OCR (e), or OCR for state 2 $(-\mathrm{ADP})$ and state $3(+\mathrm{ADP})$ respiration rates $(\mathbf{f})$. Bar graphs are expressed as a percentage of CTL and represent the mean \pm SE $(\mathrm{n}=4-6) .{ }^{*} \mathrm{p}<0.05,{ }^{*} \mathrm{p}<0.01$ vs. CTL. (fig. 1a). Moreover, cells incubated with Thap $(1 \mu \mathrm{g} / \mathrm{ml})$, Tuni $(2 \mu \mathrm{g} / \mathrm{ml})$, or ATZ $(100 \mu \mathrm{g} / \mathrm{ml})$ showed a similar decrease in viable cells (fig. $1 \mathrm{~b})$.

To test whether the ER or mitochondria stressors induced apoptotic cell death, we performed DNA fragmentation and ELISA apoptotic cell death assays. DNA laddering and the level of histone-associated DNA fragments increased following treatment with each agent $(\mathrm{p}<0.01$ vs. CTL; fig. $1 \mathrm{c}, \mathrm{d})$. These results suggest that Thap, Tuni, and ATZ treatment causes apoptosis in SHSY5Y human neuroblastoma cells.

\section{ER Stress Induces Mitochondrial Dysfunction}

Next, we investigated whether Thap and Tuni treatment disrupts mitochondrial function by examining such mitochondrial characteristics as intracellular ATP content, membrane potential $\left(\Delta \psi_{\mathrm{m}}\right)$, ROS production, and respiration. SH-SY5Y cells cultured in SFM containing $0.5 \%$ FBS were treated with DMSO alone (CTL), Thap $(1 \mu \mathrm{g} / \mathrm{ml})$, Tuni $(2 \mu \mathrm{g} / \mathrm{ml})$, or ATZ $(100 \mu \mathrm{g} / \mathrm{ml})$ for $24 \mathrm{~h}$. All three treatments reduced the intracellular ATP content and TMRE-stained mitochondrial membrane potential by $30-40 \%$ compared to the control sample (fig. 2 a, 


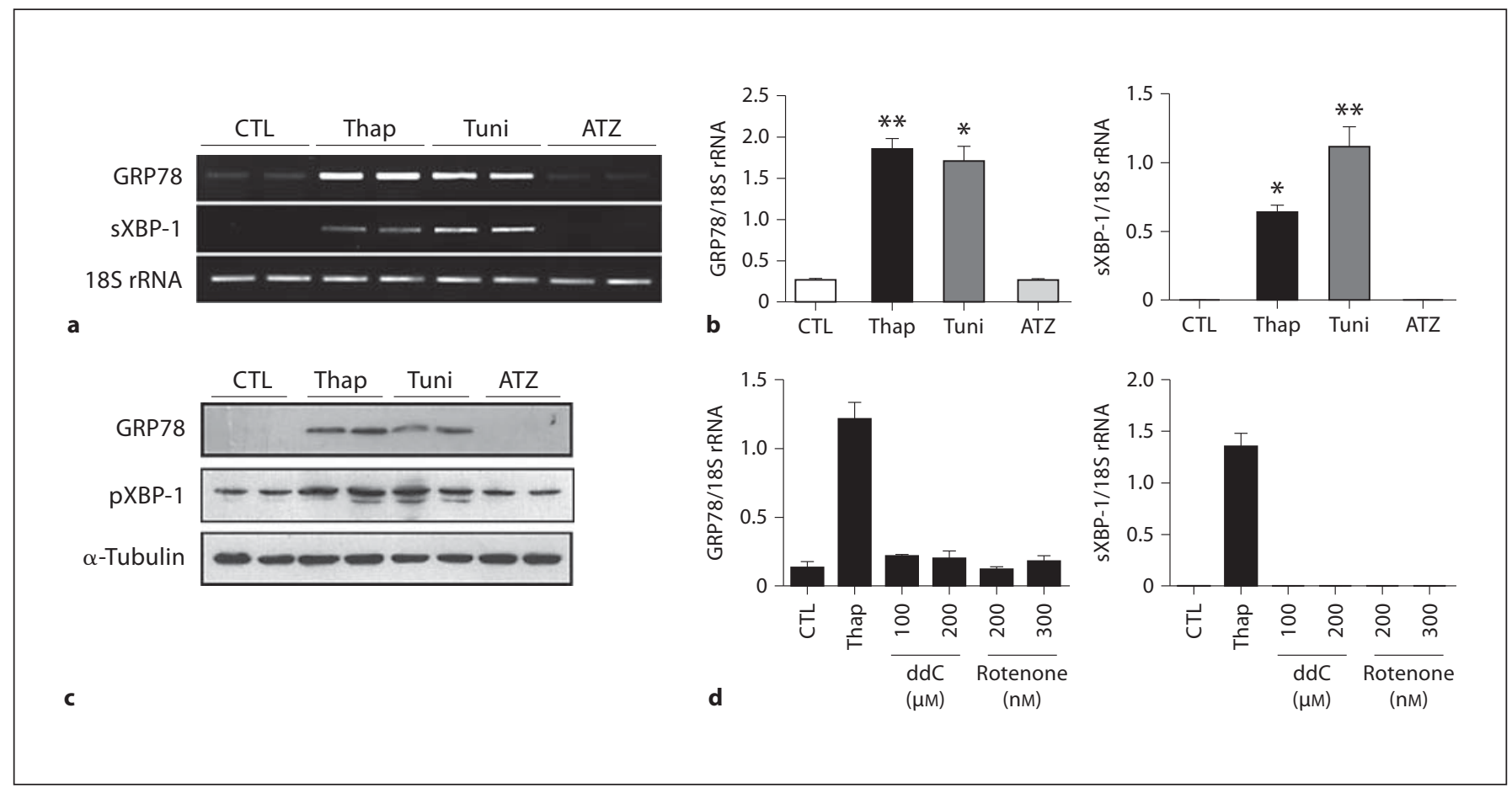

Fig. 3. Mitochondrial stress inducer ATZ did not induce ER stress markers. Total RNA was isolated from SH-SY5Y cells treated with DMSO alone (CTL), Thap (1 $\mu \mathrm{g} / \mathrm{ml})$, Tuni $(2 \mu \mathrm{g} / \mathrm{ml})$, or ATZ (100 $\mu \mathrm{g} / \mathrm{ml})$ for $24 \mathrm{~h}$. The ER stress markers GRP78 and sXBP-1 were amplified by RT-PCR and quantified by densitometry. a Representative agarose gel. b Quantitation of band intensities. Data are expressed as a percentage of CTL. c Levels of GRP78, pXBP-1, and $\alpha$-tubulin were analyzed by Western blot. d GRP78 or sXBP mRNA level in ddC- or rotenone-treated cells were determined by semiquantitative RT-PCR. Data represent the mean $\pm \operatorname{SE}(n=4)$. ${ }^{*} \mathrm{p}<0.05,{ }^{* *} \mathrm{p}<0.01$ vs. CTL. b). Likewise, two markers of oxidative stress, DCF-DAstained ROS and carbonylated proteins, also increased (fig. 2c, d).

Moreover, the coupled and FCCP-uncoupled oxygen consumption rates decreased following treatment with these agents (fig. 2e). Since the reductions in uncoupled respiration were greater than those of coupled respiration in the stress-induced cells, these agents may exhaust the maximum capacity (reservoir) of mitochondrial respiration, or OCR. This was demonstrated by measuring state 2 (-ADP) and state 3 (+ADP) OCR. When the basal, state 2 and state 3 OCRs were determined in permeabilized cells by sequential addition of pyruvate/malate substrates (state 2) and ADP (state 3), all three OCRs decreased in the stress-induced cells compared to the control sample (fig. 2f). Furthermore, state 3 respiration in Thap-, Tuni-, and ATZ-treated cells did not increase with addition of ADP in the presence of the substrates, suggesting that the respiratory capacity of these cells was reduced significantly. Taken together, these results indicate that the
ER-specific agents, Thap and Tuni, lead to ROS production by disrupting basic mitochondrial functions (ATP, $\Delta \psi_{\mathrm{m}}$, and OCR) similar to the mitochondrial stressor ATZ.

\section{ATZ Did Not Affect ER Stress-Related Gene Expression}

We also assessed whether ATZ could induce ER stress by comparing the expression of the ER stress markers GRP78 and sXBP-1 by semi-quantitative RT-PCR and Western blot in Thap-, Tuni- and ATZ-treated cells. Both Thap and Tuni induced GRP78 and sXBP-1 mRNA and protein expression. In contrast, ATZ did not enhance GRP78 and sXBP-1 expression (fig. 3a-c), suggesting that ATZ does not induce ER stress-mediated UPR. To confirm whether other mitochondrial stresses induce GRP78 or sXBP-1 expression, we treated the cells with dideoxycytidine (ddC) or rotenone [32]. Similar to ATZ, these mitochondrial stressors did not induce GRP78 and sXBP1 mRNA expression (fig. 3d). 
Fig. 4. Microarray analysis of Thap-, Tunior ATZ-treated cells. Total RNA was isolated from SH-SY5Y cells treated with DMSO (CTL), Thap (1 $\mu \mathrm{g} / \mathrm{ml})$, Tuni $(2 \mu \mathrm{g} /$ $\mathrm{ml})$, or ATZ $(100 \mu \mathrm{g} / \mathrm{ml})$ for $24 \mathrm{~h}$. The transcriptome induced by each agent was analyzed by microarray $(n=3)$. a Hierarchical clustering of the transcriptomes. Genes with a fold change (FC) greater than 1.5 exhibiting $\mathrm{p}<0.05$ were clustered. b 3DPCA. c Ingenuity pathway analysis. Genes with an FC greater than 1.2 with $\mathrm{p}<0.05$ were clustered.

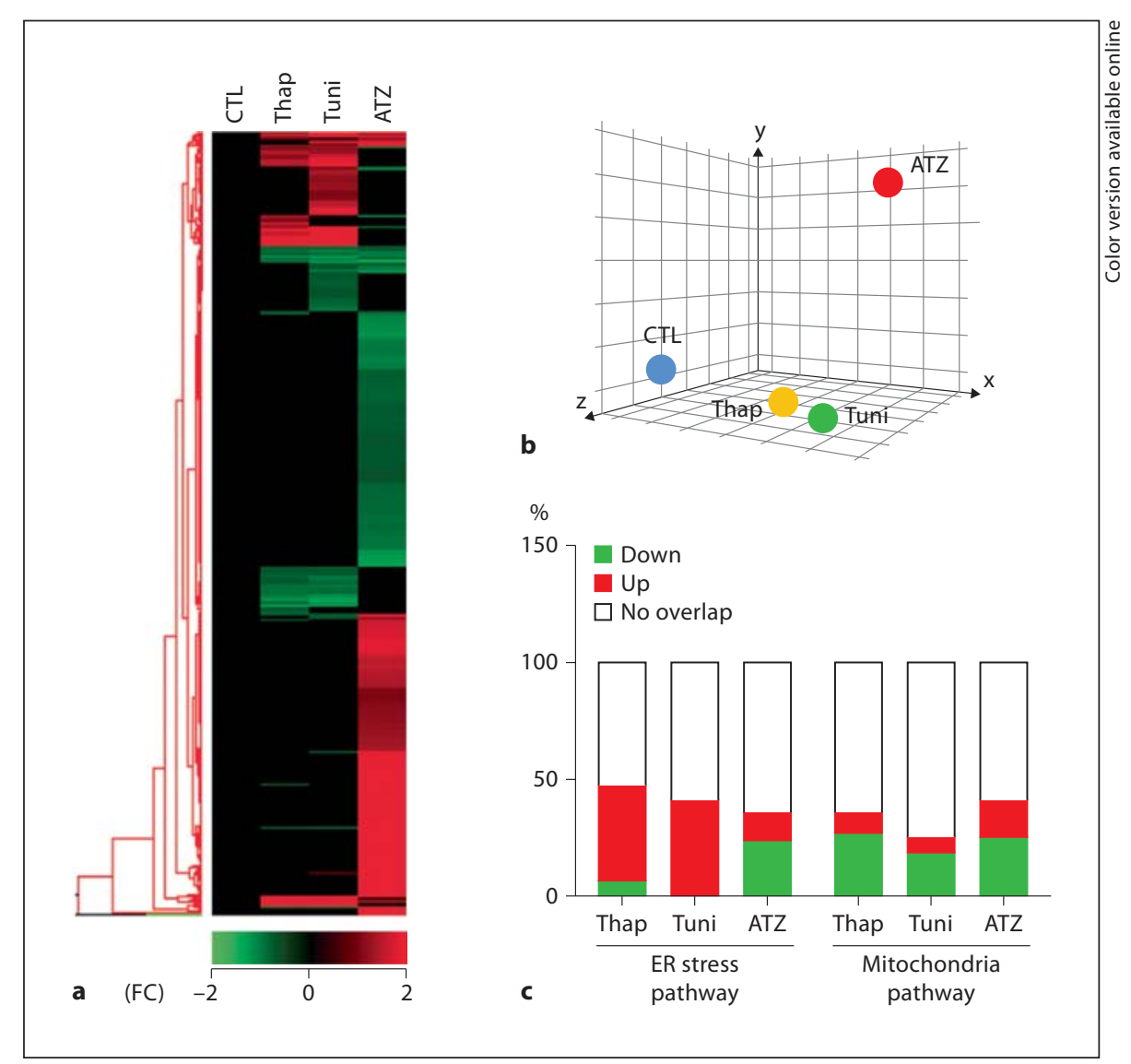

Transcriptomes of Thap-/Tuni-Treated Cells Differ from Those of ATZ-Treated Cells

We performed high-density oligonucleotide microarray analyses $(n=3)$ to determine the changes in gene expression induced by either ER or mitochondrial stress in SH-SY5Y cells. Our data demonstrate that Thap, Tuni, and ATZ treatment upregulated 314, 501, and 1,372 genes, respectively, at least 1.5 -fold $(\mathrm{p}<0.05)$. Moreover, treatment with Thap, Tuni, and ATZ led to the downregulation of 323, 509, and 1,306 genes, respectively, at least 1.5fold ( $p<0.05$; see online supplementary table S1 for list of genes; for all online supplementary material, see www. karger.com/doi/10.1159/000333069).

To compare the gene expression pattern induced by each agent, we performed hierarchical clustering analysis (fig. 4a) and 3D-PCA (fig. 4b). Thap- and Tuni-treated cells exhibited similar gene expression patterns; however, these profiles differed markedly from that of ATZ-treated cells. Analysis of pathways using the Ingenuity System revealed that most of the genes associated with ER stress signaling pathways were upregulated by Thap and Tuni treatment, but downregulated following ATZ treatment (fig. 4c). Conversely, most genes involved in mitochondrial metabolic pathways were downregulated by all three agents (fig. 4c). Lists of the common genes regulated by the various treatments are presented in online supplementary table S2.

\section{ER Stress Downregulated Mitochondria-Related Gene Expression}

Next, we performed hierarchical clustering of the 483 mitochondria-associated genes that were up- or downregulated at least 1.2 -fold ( $\mathrm{p}<0.05$; fig. $5 \mathrm{a}$; see online suppl. table S3 for list of genes). Among these, 38 and 11 genes were down- or upregulated, respectively, by all three treatments (fig. 5b, c). The downregulated genes included the nuclear DNA (nDNA)-encoded OXPHOS subunits nicotinamide adenine dinucleotide (NADH) dehydrogenase-1-beta subcomplex 8 (NDUFB8), NADH dehydrogenase-1-alpha subcomplex subunit 6 (NDUFA6), NDUFA11, NDUFA4, NDUFS5, ubiquinolcytochrome $\mathrm{c}$ reductase-binding protein (UQCRB), cy- 


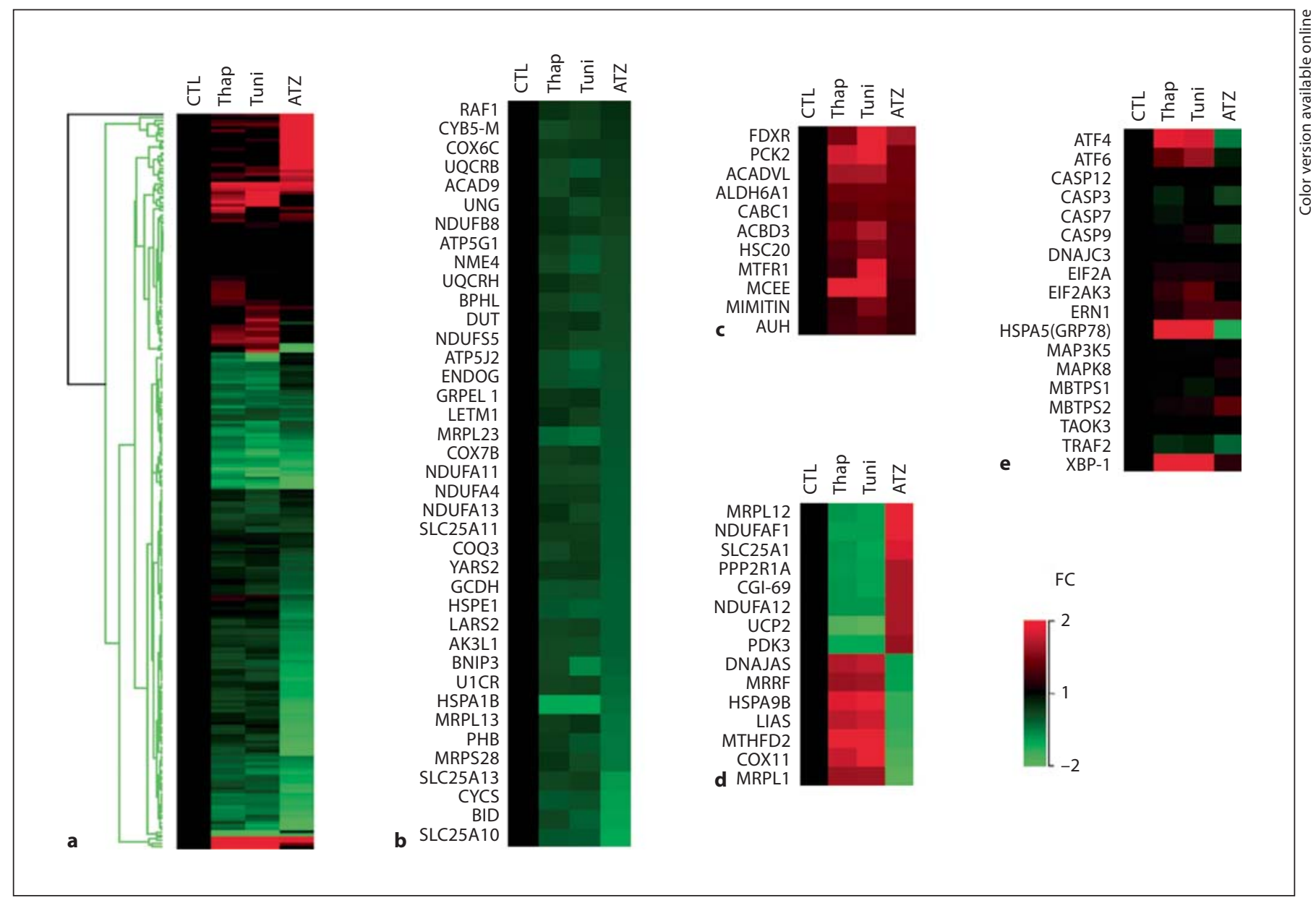

Fig. 5. Heat map of nuclear DNA-encoded genes involved in mitochondria or ER stress-related pathways. a Hierarchical clustering of all mitochondria-associated genes altered by the indicated treatment $(\mathrm{n}=3, \mathrm{p}<0.05)$. b Mitochondria-associated genes downregulated by all three treatments [fold change $(\mathrm{FC})<-1.2$ ] c Mitochondria-associated genes upregulated by all three treatments $(\mathrm{FC}>1.2)$. d Genes regulated in an opposing manner by Thap/Tuni and ATZ treatment $(\mathrm{FC}>1.2$ or FC $<-1.2)$. e Genes involved in ER stress pathways $(\mathrm{n}=3, \mathrm{p}<0.05)$. tochrome c oxidase subunit VIc (COX6C), COX7B, ATP synthase $\mathrm{F}_{0}$ complex subunit 9 (ATP5G1), and ATP5J2. Expression of genes involved in fatty acid metabolism and mitochondrial OXPHOS, which may compensate for mitochondrial damage, were upregulated by the agents. Some mitochondria-related genes induced by ER stress exhibited an opposite expression pattern in response to ATZ treatment (fig. 5d). On the contrary, expression of only 15 genes associated with the ER stress pathway was altered in an opposing manner by the agents $(\mathrm{p}<0.05)$. For instance, Thap and Tuni treatment augmented ATF4, GRP78, and XBP-1 mRNA levels while ATZ reduced them (fig. 5e). This opposing regulation is consistent with the data presented in figure 3 , suggesting that ER stress represses the expression of genes involved in mitochond rial function, thereby leading to mitochondrial dysfunction similar to that induced by mitochondrial stress. Furthermore, our data demonstrate that markers of ER stress are not induced by mitochondrial stress.

\section{ER Stress Downregulated the mtDNA-Encoded 13 OXPHOS Subunits}

Because the mtDNA-encoded 13 subunits of OXPHOS complexes were not included on the human Illumina bead chip, we analyzed these transcripts by semiquantitative RT-PCR. This experiment revealed that the expression of all $13 \mathrm{mtDNA}$-encoded OXPHOS subunits was decreased 


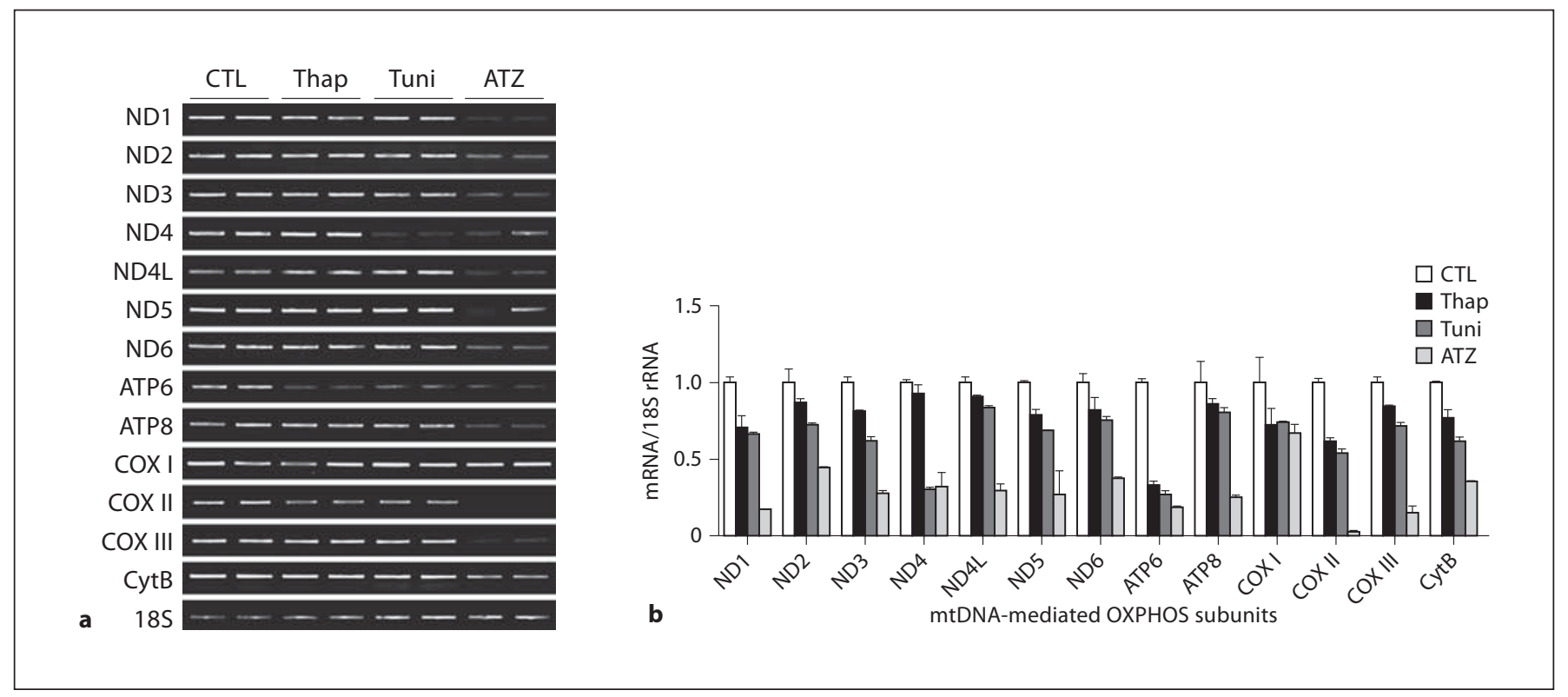

Fig. 6. Semiquantitative RT-PCR of mtDNA-encoded OXPHOS subunits. Total RNA was isolated from SH-SY5Y cells treated with DMSO (CTL), Thap $(1 \mu \mathrm{g} / \mathrm{ml})$, Tuni $(2 \mu \mathrm{g} / \mathrm{ml})$, or ATZ $(100 \mu \mathrm{g} /$ $\mathrm{ml}$ ) for $24 \mathrm{~h}$, and mRNA for mtDNA-encoded OXPHOS subunits were examined by semiquantitative RT-PCR. a Representative PCR products on an agarose gel. $\mathbf{b}$ Band intensities of the PCR products were quantified and normalized to the level of $18 \mathrm{~S}$ rRNA. Fold induction vs. CTL was graphed $(n=6)$. up to approximately $90 \%$ by ATZ while treatment with Thap or Tuni resulted in a $20-40 \%$ reduction (fig. 6).

Variable Effects of ER Stress on nDNA-Encoded OXPHOS Subunits and Mitochondrial Biogenesis

Factors

Pathway analysis using Ingenuity System showed that the expression of most OXPHOS complex subunits was decreased by all three treatments (online suppl. fig. S1). To validate these results, we performed semiquantitative RT-PCR for two nDNA-encoded genes per OXPHOS complex (fig. 7). Our data revealed the decrease in NDUFA6, SDHC, UQCRC1, and COX7B expression, as well as the increase in NDUFB9 and SDHA mRNA. The remaining OXPHOS subunits, COX5B, ATP5A1 and ATP5O, were not altered significantly. Among the mitochondrial biogenesis-related genes, Thap and Tuni reduced the transcripts of mitochondrial transcription factor A (TFAM), nuclear respiratory factor 1 (NRF-1), uncoupling protein 2 (UCP2), somatic cytochrome c (CYCS), manganese superoxide dismutase (SOD2, MnSOD), sirtuin 3 (SIRT3), and phosphoenolpyruvate carboxykinase 2 (PCK2). Here, the changes in SOD2, SIRT3, and PCK2 were not consistent with the results of microarray. In addition, ATZ suppressed the expression of all mitochondrial biogenesis-related genes tested, including peroxisome proliferator-activated receptor- $\gamma$ (PPAR $\gamma$ ) coactivator- $1 \alpha$ (PPRC1, PGC- $1 \alpha$ ) and SIRT1, except PCK2 and UCP2. We noted the complete suppression of CYCS and SOD2 by semiquantitative RT-PCR, suggesting that they may serve as critical markers or denominators of ER and mitochondrial stress.

We constructed a heat map to summarize the quantitative changes in mitochondrial activity and validated gene expression (fig. 8). The heat map clearly demonstrates that treatment with Thap, Tuni, and ATZ decreased mitochondrial activity as well as the expression of mtDNA-encoded OXPHOS subunits, most nDNA-encoded OXPHOS subunits, and the mitochondrial control system. As expected, all treatments increased ROS production. Interestingly, some nDNA-encoded OXPHOS subunits, such as NDUFB9 and SDHA, were regulated in an opposing manner by Thap, Tuni or ATZ.

\section{ER Stress Impairs the Insulin Signaling Pathway}

Mitochondrial dysfunction has been implicated as a central cause of insulin resistance [35-37]. Thus, to test whether ER stress-induced mitochondrial dysfunction 


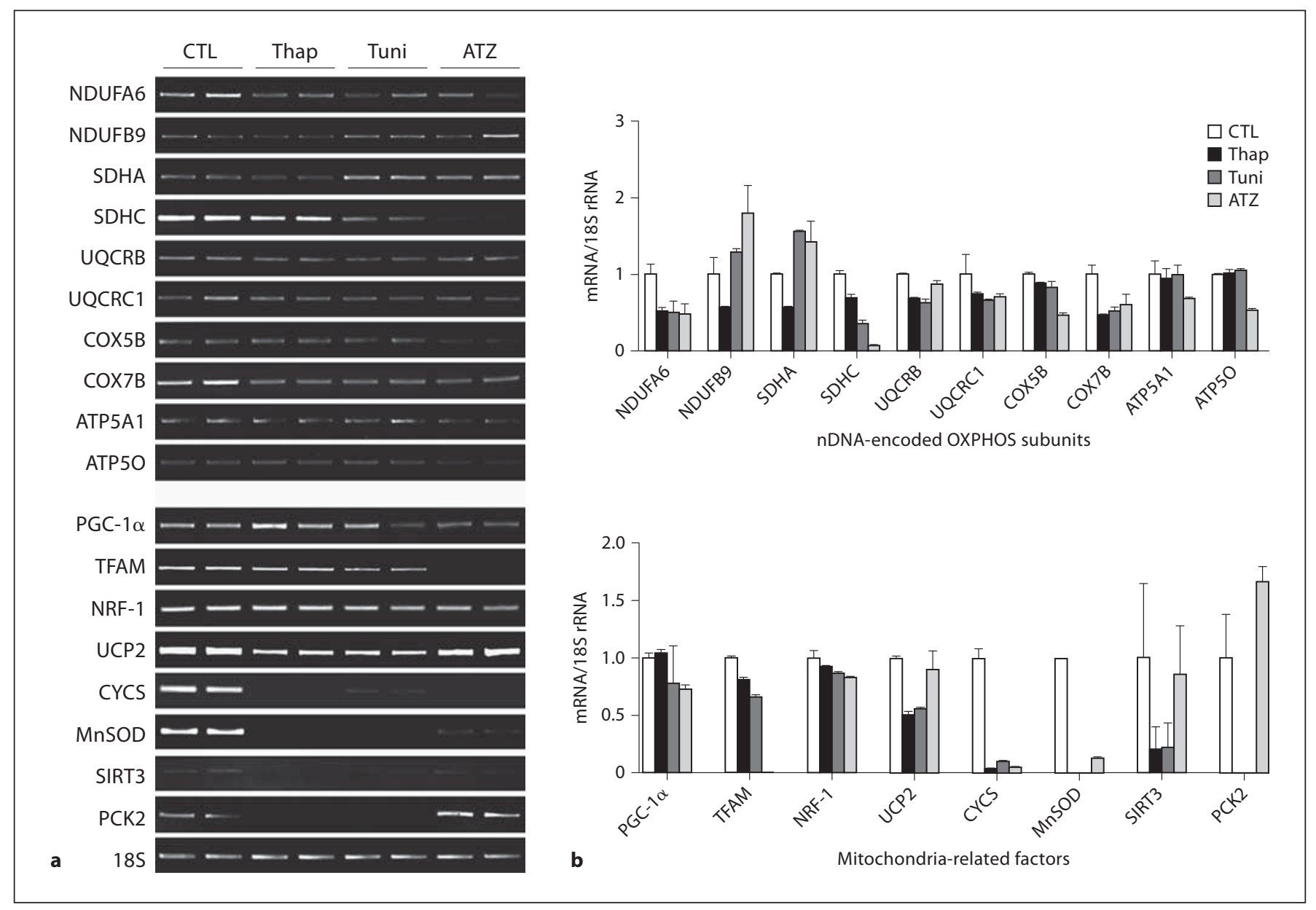

Fig. 7. RT-PCR validation of nDNA-encoded OXPHOS subunits and mitochondria-related factors. Total RNA was isolated and analyzed by semiquantitative RT-PCR as described in figure 6 . a Representative PCR products on an agarose gel. $\mathbf{b}$ Band intensities were quantified and normalized to the level of $18 \mathrm{~S}$ rRNA. Fold induction vs. CTL was graphed $(n=6)$. caused insulin resistance in SH-SY5Y cells, we analyzed the phosphorylation states of IRS-1 and Akt1, which are key molecules for insulin signaling. In the Thap-, Tuniand ATZ-treated cells, pIRS-1 (S307) was increased, whereas pIRS-1 (Y632) was decreased (fig. 9a). It must be noted that treatment with Thap and Tuni, but not ATZ, decreases total IRS-1 protein. Basal Akt phosphorylation at S473, but not at T308, was markedly reduced by the agents, indicating that Thap, Tuni, and ATZ cause defects in IRS-1 and Akt phosphorylation, possibly leading to insulin resistance in neuronal cells. To confirm if the agenttreated cells are resistant to insulin stimulation, we stimulated the Thap-, Tuni-, and ATZ-treated cells with 100 $\mathrm{nM}$ insulin for $30 \mathrm{~min}$ and the levels of pIRS and pAkt were determined. As shown in figure 9b, insulin stimulation did not phosphorylate IRS at both Y632 and S307 in

ER Stress-Induced Mitochondrial

Dysfunction in Neurodegeneration the treated cells. Similarly, insulin failed to phosphorylate Akt at S473 in ATZ-treated cells, while it failed to phosphorylate Akt at T308 in Thap- and Tuni-treated cells. The ratios of pAkt/Akt were determined after quantification of the band intensities (fig. 9c, n=3). It is not yet clear why the stresses affected Akt phosphorylations at different sites. Our proposed model of interactions between the two stresses, mitochondria, and the insulin signaling cascade is diagrammed in figure $9 \mathrm{~d}$.

\section{Ectopic Overexpression of TFAM or NRF-1 \\ Ameliorates ER Stress-Induced Impairment of \\ Mitochondria and Akt Phosphorylation}

We have reported that mitochondrial dysfunction decreases the level of phosphorylated Akt(S473) in vascular smooth muscle cells [32]. To verify whether mitochondrial 


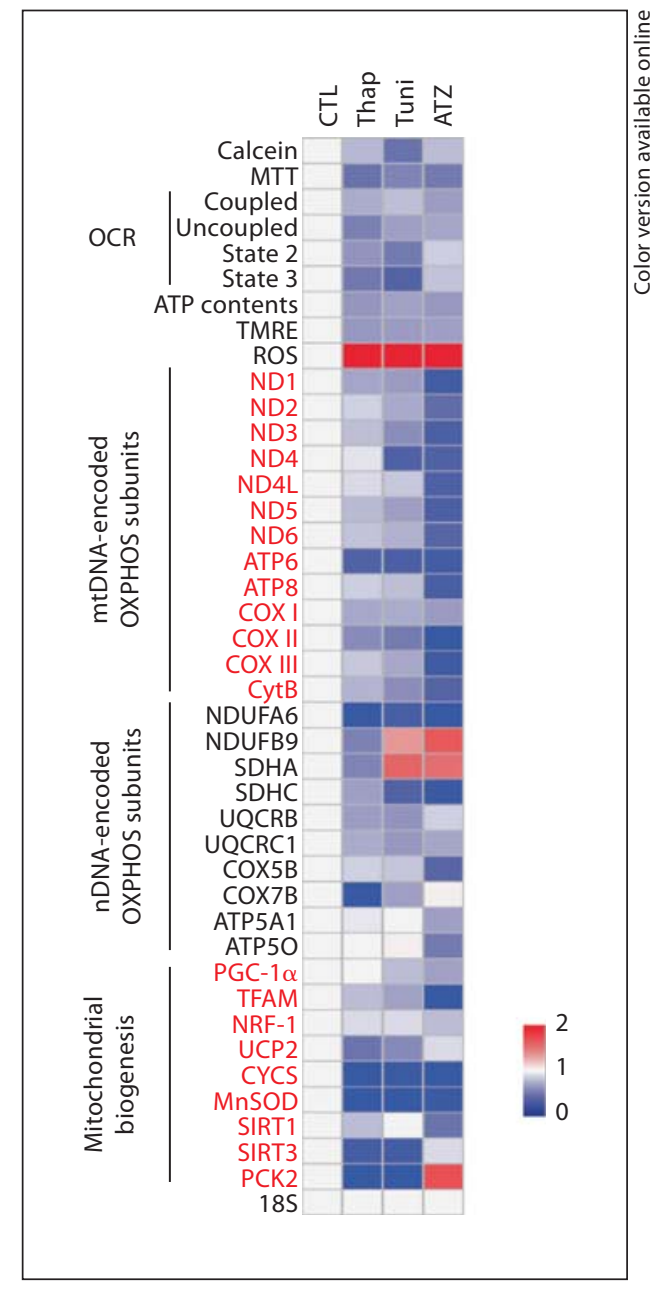

Fig. 8. Heat map of parameters from a cell-based mitochondrial activity profiling system. All parameters of mitochondrial functions and gene expression level were summarized as a heat map. Most parameters were decreased except for ROS. NDUFB9, SDHA and PCK2 showed opposite alterations by different treatments.

damage is involved in the ER stress-mediated reduction of phosphorylated Akt(S473), we transiently transfected SHSY5Y cells with plasmids expressing TFAM or NRF-1 and then treated the cells with Thap. Both of these proteins have been reported to enhance mitochondrial biogenesis and regulate mitochondrial functions [32, 38]. As shown in figure 10, overexpression of either NRF-1 or TFAM partially restored most facets of mitochondrial function tested, including complex I activity (fig. 10a), ATP content (fig. 10b), and ROS generation (fig. 10d), except mitochondrial membrane potential (fig. 10c), back to normal levels. Moreover, the level of phosphorylated Akt(S473), ND9 in complex 1, and tyrosine hydroxylase (TH), a functional marker for dopaminergic neuronal cells, also recovered (fig. 10e). However, PGC-1 $\alpha$, another mitochondrial biogenesis control factor, was not altered by NRF-1 or TFAM overexpression during Thap treatment.

\section{Discussion}

Aging and many neurodegenerative diseases have been associated with ER stress and mitochondrial dysfunction. The ER and mitochondria communicate with each other by releasing factors such as calcium or ROS. Although mitochondrial dysfunction is generally accepted as a cause of insulin resistance in peripheral tissues, it is not clearly understood whether ER or mitochondrial stress is directly involved in the degeneration of neuronal cells [39]. In the present study, we demonstrated that both Thap- and Tuniinduced ER stress impaired the insulin signaling pathway and mitochondria in SH-SY5Y human neuroblastoma cells. Similarly, an inducer of mitochondrial stress, namely ATZ, also blocked mitochondrial function and insulin signaling. In particular, Thap and Tuni treatments impaired various aspects of mitochondrial function from physiology to gene expression, while ATZ did not significantly alter the expression of ER stress marker genes. Microarray analysis confirmed the relationship between the ER and mitochondrial stress in neuronal cells: although disruption of the ER induces mitochondrial stress, mitochondrial dysfunction does not lead to ER stress.

Cell culture studies using inducers of ER stress are relatively well established. Thap or Tuni treatment disrupts ER function effectively and induces neuronal cell apoptosis [40]; however, pharmacological induction of mitochondrial toxicity has not been as clearly defined. Rotenone, 6-hydroxydopamine (6-OHDA), and 1-methyl-4phenylpyridinium (MPP+), which inhibit mitochondrial OXPHOS complex 1, are useful to construct PD models [41]. Since these agents also induced ER stress and unfolded protein response (UPR) in neuronal PC12 cells [42], we expected that another mitochondrial toxin, ATZ, would induce ER stress along with mitochondrial damage in SH-SY5Y cells. We have previously demonstrated that ATZ represses mitochondrial OXPHOS by inhibiting Coenzyme $\mathrm{Q}$ and induces insulin resistance in vivo and in vitro [28]. However, in SH-SY5Y cells, mitochondrial toxins such as ATZ, rotenone, and ddC did not markedly enhance the expression of GRP78 and spliced XBP-1, two ER stress markers (fig. 3). There are several reports showing that different cell types respond variably 

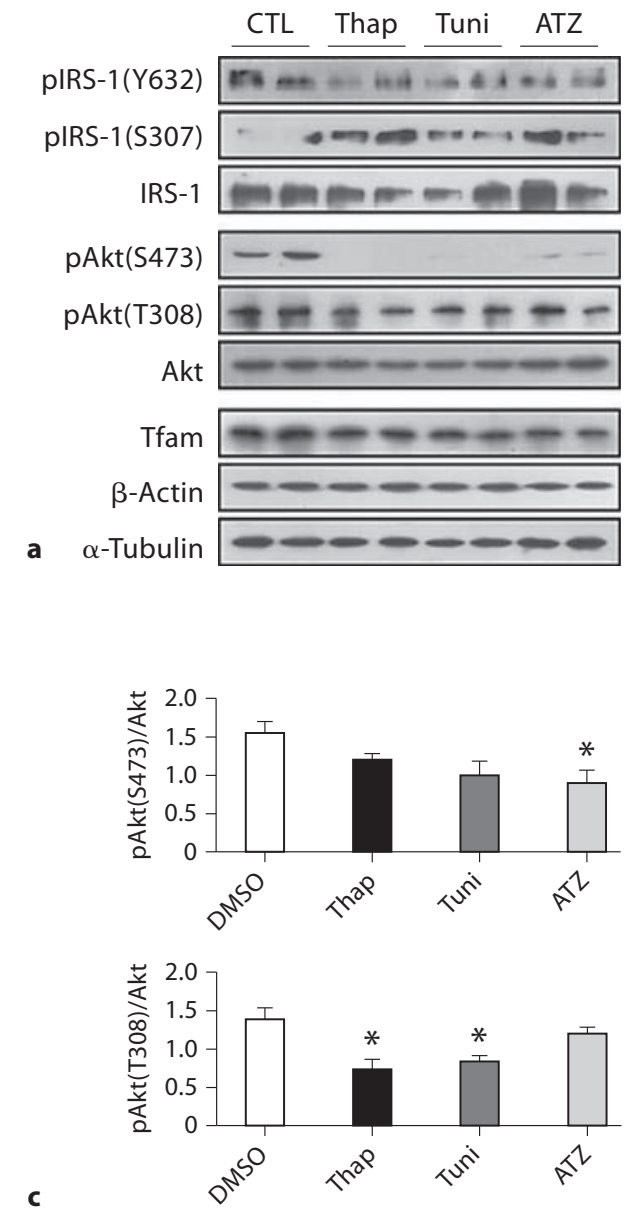
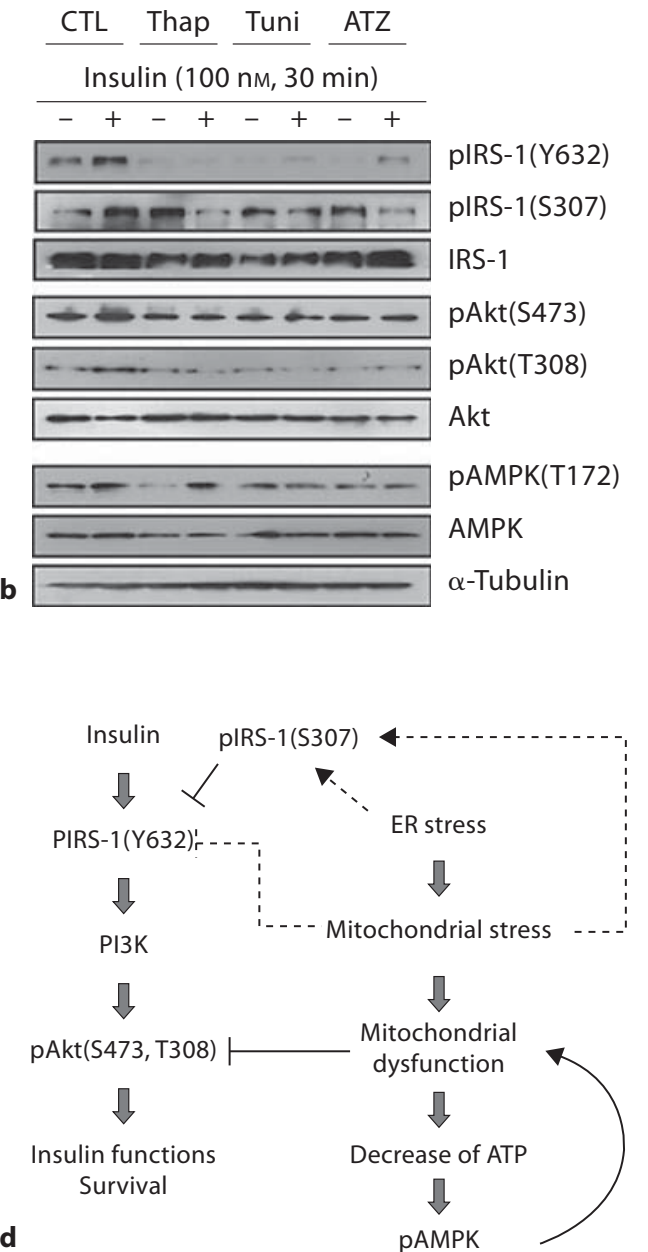

Fig. 9. Impairment of insulin signaling by both ER and mitochondrial stress. a SH-SY5Y cells cultured in serum-free media were incubated with DMSO alone (CTL), Thap $(1 \mu \mathrm{g} / \mathrm{ml})$, Tuni $(2 \mu \mathrm{g} /$ $\mathrm{ml})$, or ATZ $(100 \mu \mathrm{g} / \mathrm{ml})$ for $24 \mathrm{~h}$, harvested, and then analyzed by Western blot using antibodies against the indicated proteins involved in insulin signaling. b SH-SY5Y cells in low-glucose DMEM containing $0.5 \%$ FBS were incubated with DMSO vehicle
(CTL), Thap (1 $\mu \mathrm{g} / \mathrm{ml})$, Tuni $(2 \mu \mathrm{g} / \mathrm{ml})$, or ATZ $(100 \mu \mathrm{g} / \mathrm{ml})$ for $24 \mathrm{~h}$, and treated with or without insulin (100 nM for $30 \mathrm{~min}$ ), then harvested and analyzed by Western blot. c The levels of Akt phosphorylation at $\mathrm{S} 473$ or T308 were quantified by densitometry ( $\mathrm{n}=3{ }^{*} \mathrm{p}<0.05$ vs. DMSO). d Schematic model showing the interactions between mitochondria and the insulin signaling pathway. to ER or mitochondrial disruption despite inducing ER stress markers, research indicates. For example, the highfat diet as a metabolic inflammatory mediator disrupted ER functions in the liver, skeletal muscle [43], adipocytes [9], and hypothalamus [44]. It also induced serine phosphorylation of IRS- 1 by activating c-Jun N-terminal kinase-1, consequently resulting in hepatic insulin resistance [9]. On the contrary, in pancreatic beta cells and skeletal muscle, stress induced by the same high-fat diet failed to impair insulin secretion and ER function despite activation of ER stress markers [45]. However, mitochondrial damage and blockage of insulin signaling were often observed in stressed tissues, indicating that mitochondrial dysfunction is the primary cause of pathogenesis.

The ER delivers dysfunctional signals to adjacent organelles, activates defense mechanisms, and restores cellular functions. ER stress induces many chaperone proteins and transcription factors, including GRP78, ATF6, and XBP-1, which play roles in repairing protein unfold- 


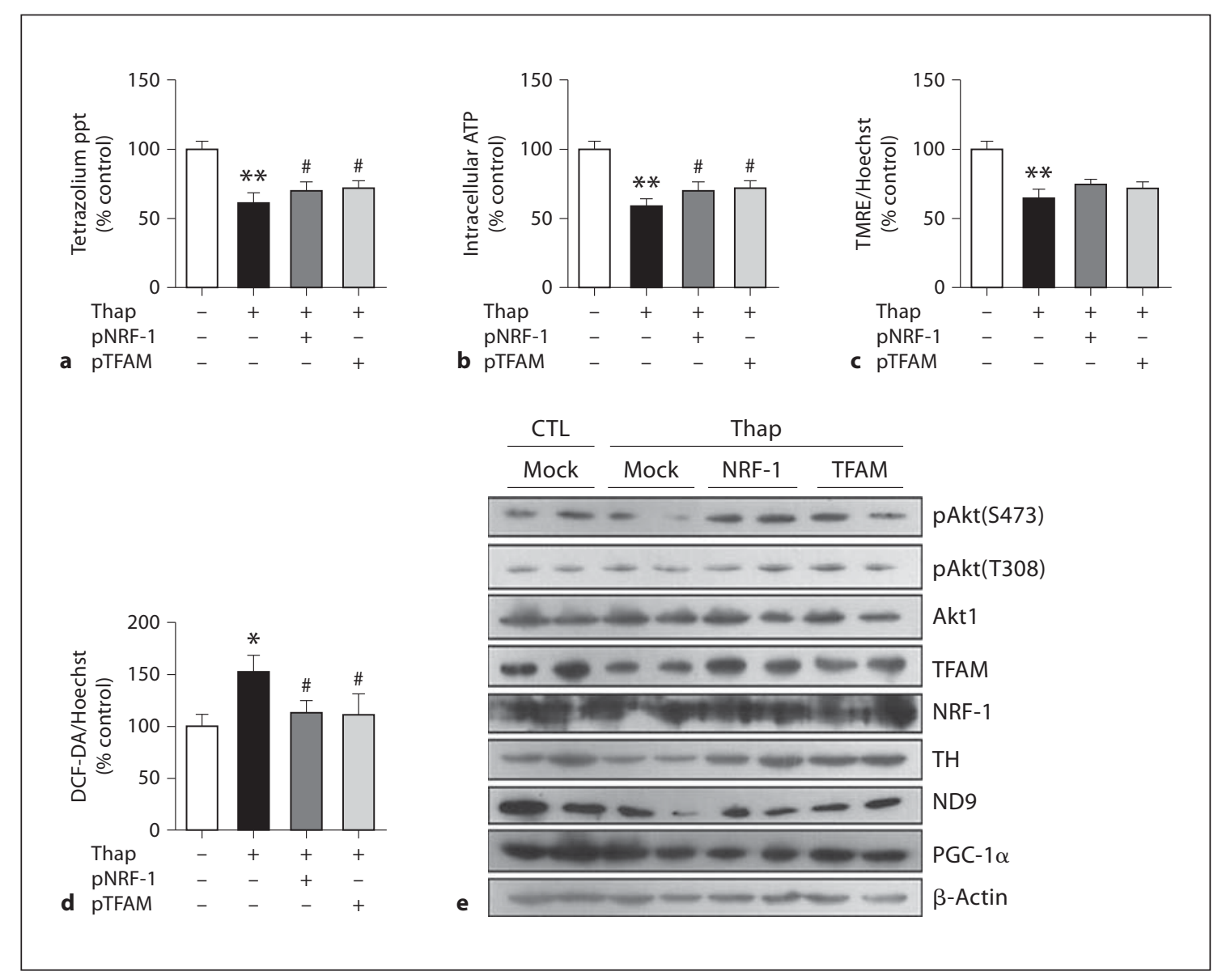

Fig. 10. Recovery of mitochondrial functions and Akt phosphorylation by ectopic overexpression of NRF-1 or TFAM. The SHSY5Y cells in 24 -well plate were transfected with $1 \mu \mathrm{g}$ plasmid expressing NRF-1 or TFAM and incubated with DMSO alone or Thap $(1 \mu \mathrm{g} / \mathrm{ml})$ for $24 \mathrm{~h}$ as indicated. The cells were harvested and analyzed for NADH dehydrogenase activity (MTT assay) (a), intracellular ATP content (b), mitochondrial membrane potential (c), ROS generation (d), and proteins involved in insulin signaling and mitochondrial biogenesis (e). Data represent the mean $\pm \mathrm{SE}$ $(\mathrm{n}=4) .{ }^{*} \mathrm{p}<0.05,{ }^{* *} \mathrm{p}<0.01$ vs. CTL, ${ }^{\#} \mathrm{p}<0.05$ vs. Thap. ing and increase the expression of chaperone proteins. But it is controversial whether such ER stress-induced factors protect cell viability. Deletion of the GRP78 gene protected against apoptosis in a neurotoxin-induced PD model, suggesting that this chaperone may mediate neuronal death [46]. However, XBP-1-deficient mice were more resistant to the amyotrophic lateral sclerosis neurodegenerative disease, which is inconsistent with the severity of the disease [47]. In Caenorhabditis elegans, IRE-1 and XBP-1 are involved in prolonging life span and enhancing resistance to ER stress by interacting with DAF-16, a forkhead box O (FOXO) transcription factor, in the insulin signaling pathway [48]. While ER stress-induced factors are involved in cellular viability, ROS accumulation is considered a major cause of apoptosis or cy- totoxicity in most neurodegenerative diseases, implying that ER stress-induced blockage of mitochondrial electron transfer may contribute to enhance the production of ROS. It is not clear yet, however, why dopaminergic neuronal cells are especially vulnerable to mitochondrial toxins and why neuronal cells respond differently to others.

Our data contradict a few studies that report mitochondrial stressors that induce the ER stress. In adipocytes and myocytes, $6 \mathrm{~h}$ treatment with mitochondrial stressors such as indinavir, chloramphenicol, CCCP, and oligomycin induced ATF3, thereby causing a reduction in adiponectin expression $[45,49]$. We noted that these chemicals increased NRF-1, as well as p-eIF $2 \alpha$ and spliced XBP-1. The observed transient increase in NRF-1 may enhance mitochondrial biogenesis to compensate for 
mitochondrial damages. Also, mitochondrial stress-induced ER dysfunction would exacerbate the disease but still play a minor role in pathogenesis.

We have also shown previously that mitochondrial toxins, including ATZ, block the insulin-signaling pathway at the level of IRS-1 or Akt [32]. Similarly, Thap or Tuni treatment suppressed phosphorylation of IRS-1 and Akt(S473). Neither ER stress nor ATZ affected threonine phosphorylation of Akt at position 308, suggesting that the PI3K-, not PDK-, dependent pathway, may be repressed by these pharmacological agents. Furthermore, NRF-1 and TFAM overexpression restored mitochondrial function, insulin signaling, and $\mathrm{TH}$ expression in neuronal cells (fig. 10). A similar recovery in adiponectin transcription was also reported in adipocytes [49]. Collectively, our results suggest that mitochondrial repression is the central cause of neuronal cell degeneration and thus is a good candidate as a therapeutic target.

In summary, we demonstrate that both ER and mitochondrial inhibitors induce neuronal cell death via over- lapping dysfunction in mitochondria, but that ER dysfunction was rarely induced by mitochondrial inhibitors. Furthermore, both ER and mitochondrial stresses disrupt the insulin signaling pathway by reducing IRS-1 and Akt phosphorylation. Our data suggest that ER stress impairs insulin signaling through mitochondrial dysfunction in neuronal cells and re-activation of mitochondrial functions may be a good therapeutic strategy for overcoming neurodegeneration. These results provide a better understanding of the pathogenesis of neurodegenerative diseases and assist in developing new treatments.

\section{Acknowledgements}

This study was supported by grants from the National Research Foundation of Korea $(20090063278,20090084158$, and 20090084844) and FPR08A1-070 of 21C Frontier Functional Proteomics Project funded by MEST, Korea.

\section{References}

- 1 Wong WL, Brostrom MA, Kuznetsov G, Gmitter-Yellen D, Brostrom CO: Inhibition of protein synthesis and early protein processing by thapsigargin in cultured cells. Biochem J 1993;289:71-79.

$\checkmark 2$ Tabas I: The role of endoplasmic reticulum stress in the progression of atherosclerosis. Circ Res 2010;107:839-850.

$\checkmark 3$ Xu C, Bailly-Maitre B, Reed JC: Endoplasmic reticulum stress: cell life and death decisions. J Clin Invest 2005;115:2656-2664.

4 Schroder M, Kaufman RJ: ER stress and the unfolded protein response. Mutat Res 2005; 569:29-63.

$\checkmark 5$ Rao RV, Bredesen DE: Misfolded proteins, endoplasmic reticulum stress and neurodegeneration. Curr Opin Cell Biol 2004;16: 653-662.

6 Ron D, Walter P: Signal integration in the endoplasmic reticulum unfolded protein response. Nat Rev Mol Cell Biol 2007;8:519-529.

-7 Katayama T, Imaizumi K, Manabe T, Hitomi J, Kudo T, Tohyama M: Induction of neuronal death by ER stress in Alzheimer's disease. J Chem Neuroanat 2004;28:67-78.

$>8$ Paschen W, Mengesdorf T: Endoplasmic reticulum stress response and neurodegeneration. Cell Calcium 2005;38:409-415.

-9 Ozcan U, Cao Q, Yilmaz E, Lee AH, Iwakoshi NN, Ozdelen E, Tuncman G, Gorgun C, Glimcher LH, Hotamisligil GS: Endoplasmic reticulum stress links obesity, insulin action, and type 2 diabetes. Science 2004;306:457461.
10 Pak YK, Jeong JH: Mitochondria: the secrete chamber of therapeutic targets for age-associated degenerative diseases. Biomolec Ther 2010;18:235-245.

11 Lin MT, Beal MF: Mitochondrial dysfunction and oxidative stress in neurodegenerative diseases. Nature 2006;443:787-795.

12 Lindholm D, Wootz H, Korhonen L: ER stress and neurodegenerative diseases. Cell Death Differ 2006;13:385-392.

13 Soto C: Unfolding the role of protein misfolding in neurodegenerative diseases. Nat Rev Neurosci 2003;4:49-60.

14 Pizzo P, Pozzan T: Mitochondria-endoplasmic reticulum choreography: structure and signaling dynamics. Trends Cell Biol 2007; 17:511-517.

15 de Brito OM, Scorrano L: Mitofusin 2 tethers endoplasmic reticulum to mitochondria. Nature 2008;456:605-610.

16 Hayashi T, Su TP: Sigma-1 receptor chaperones at the er-mitochondrion interface regulate $\mathrm{Ca}(2+)$ signaling and cell survival. Cell 2007;131:596-610.

17 Dou JT, Chen M, Dufour F, Alkon DL, Zhao WQ: Insulin receptor signaling in long-term memory consolidation following spatial learning. Learn Mem 2005;12:646-655.

18 Watson GS, Craft S: The role of insulin resistance in the pathogenesis of Alzheimer's disease: implications for treatment. CNS Drugs $2003 ; 17: 27-45$
19 Morris JK, Zhang H, Gupte AA, Bomhoff GL, Stanford JA, Geiger PC: Measures of striatal insulin resistance in a 6-hydroxydopamine model of Parkinson's disease. Brain Res 2008;1240:185-195.

20 de la Monte SM: Insulin resistance and Alzheimer's disease. BMB Rep 2009;42:475481 .

21 Alessi DR, James SR, Downes CP, Holmes $A B$, Gaffney PR, Reese CB, Cohen P: Characterization of a 3-phosphoinositide-dependent protein kinase which phosphorylates and activates protein kinase Balpha. Curr Biol 1997; 7:261-269.

22 Aguirre V, Werner ED, Giraud J, Lee YH, Shoelson SE, White MF: Phosphorylation of ser307 in insulin receptor substrate-1 blocks interactions with the insulin receptor and inhibits insulin action. J Biol Chem 2002; 277:1531-1537.

23 Tzatsos A, Tsichlis PN: Energy depletion inhibits phosphatidylinositol 3-kinase/Akt signaling and induces apoptosis via AMPactivated protein kinase-dependent phosphorylation of IRS-1 at Ser-794. J Biol Chem 2007;282:18069-18082.

24 Ueki K, Yamamoto-Honda R, Kaburagi Y, Yamauchi T, Tobe K, Burgering BM, Coffer PJ, Komuro I, Akanuma Y, Yazaki Y, Kadowaki T: Potential role of protein kinase B in insulin-induced glucose transport, glycogen synthesis, and protein synthesis. J Biol Chem 1998;273:5315-5322. 
25 Wang Q, Somwar R, Bilan PJ, Liu Z, Jin J, Woodgett JR, Klip A: Protein kinase B/Akt participates in Glut 4 translocation by insulin in 16 myoblasts. Mol Cell Biol 1999;19:40084018.

26 Matsumoto M, Ogawa W, Teshigawara K, Inoue H, Miyake K, Sakaue H, Kasuga M: Role of the insulin receptor substrate 1 and phosphatidylinositol 3-kinase signaling pathway in insulin-induced expression of sterol regulatory element binding protein $1 \mathrm{C}$ and glucokinase genes in rat hepatocytes. Diabetes 2002;51:1672-1680.

-27 Berggreen C, Gormand A, Omar B, Degerman E, Goransson O: Protein kinase B activity is required for the effects of insulin on lipid metabolism in adipocytes. Am J Physiol Endocrinol Metab 2009;296:E635-E646.

-28 Lim S, Ahn SY, Song IC, Chung MH, Jang HC, Park KS, Lee KU, Pak YK, Lee HK: Chronic exposure to the herbicide, atrazine, causes mitochondrial dysfunction and insulin resistance. PLoS One 2009;4:e5186.

29 Choi YS, Lee HK, Pak YK: Characterization of the $5^{\prime}$-flanking region of the rat gene for mitochondrial transcription factor A (TFAM). Biochim Biophys Acta 2002;1574: 200-204.

30 Choi YS, Lee KU, Pak YK: Regulation of mitochondrial transcription factor a expression by high glucose. Ann NY Acad Sci 2004 1011:69-77.

-31 Han CY, Pak YK: Oxidation-dependent effects of oxidized LDL: proliferation or cell death. Exp Mol Med 1999;31:165-173.

- 32 Ahn SY, Choi YS, Koo HJ, Jeong JH, Park WH, Kim M, Piao Y, Pak YK: Mitochondrial dysfunction enhances the migration of vascular smooth muscles cells via suppression of AKT phosphorylation. Biochim Biophys Acta 2010;1800:275-281.
Park KW, Baik HH, Jin BK: Il-13-induced oxidative stress via microglial NADPH oxidase contributes to death of hippocampal neurons in vivo. J Immunol 2009;183:46664674.

34 Ahn SY, Choi YS, Koo HJ, Jeong JH, Park WH, Kim M, Piao Y, Pak YK: Mitochondrial dysfunction enhances the migration of vascular smooth muscles cells via suppression of AKT phosphorylation. Biochim Biophys Acta 2010;1800:275-281.

35 Kim JA, Wei Y, Sowers JR: Role of mitochondrial dysfunction in insulin resistance. Circ Res 2008;102:401-414.

36 Petersen KF, Befroy D, Dufour S, Dziura J, Ariyan C, Rothman DL, DiPietro L, Cline GW, Shulman GI: Mitochondrial dysfunction in the elderly: possible role in insulin resistance. Science 2003;300:1140-1142.

37 Park KS, Nam KJ, Kim JW, Lee YB, Han CY, Jeong JK, Lee HK, Pak YK: Depletion of mitochondrial DNA alters glucose metabolism in SK-Hep1 cells. Am J Physiol Endocrinol Metab 2001;280:E1007-E1014.

38 Larsson NG: Somatic mitochondrial DNA mutations in mammalian aging. Annu Rev Biochem 2010;79:683-706.

39 Obeso JA, Rodriguez-Oroz MC, Goetz CG, Marin C, Kordower JH, Rodriguez M, Hirsch EC, Farrer M, Schapira AH, Halliday G: Missing pieces in the Parkinson's disease puzzle. Nat Med 2010;16:653-661.

40 Choi AY, Choi JH, Lee JY, Yoon KS, Choe W, $\mathrm{Ha}$ J, Yeo EJ, Kang I: Apigenin protects Ht22 murine hippocampal neuronal cells against endoplasmic reticulum stress-induced apoptosis. Neurochem Int 2010;57:143-152.

41 Dauer W, Przedborski S: Parkinson's disease: mechanisms and models. Neuron 2003; 39:889-909.

42 Ryu EJ, Harding HP, Angelastro JM, Vitolo OV, Ron D, Greene LA: Endoplasmic reticulum stress and the unfolded protein response in cellular models of Parkinson's disease. J Neurosci 2002;22:10690-10698.
43 Deldicque L, Cani PD, Philp A, Raymackers JM, Meakin PJ, Ashford ML, Delzenne NM, Francaux M, Baar K: The unfolded protein response is activated in skeletal muscle by high-fat feeding: potential role in the downregulation of protein synthesis. Am J Physiol Endocrinol Metab 2010;299:E695-E705.

44 Zhang X, Zhang G, Zhang H, Karin M, Bai H, Cai D: Hypothalamic IKKbeta/NF-kap$\mathrm{paB}$ and ER stress link overnutrition to energy imbalance and obesity. Cell 2008; 135 : 61-73.

45 Park HJ, Kang YM, Kim CH, Jung MH: ATF3 negatively regulates adiponectin receptor 1 expression. Biochem Biophys Res Commun 2010;400:72-77.

46 Silva RM, Ries V, Oo TF, Yarygina O, Jackson-Lewis V, Ryu EJ, Lu PD, Marciniak SJ, Ron D, Przedborski S, Kholodilov N, Greene LA, Burke RE: CHOP/GADD153 is a mediator of apoptotic death in substantia nigra dopamine neurons in an in vivo neurotoxin model of parkinsonism. J Neurochem 2005; 95:974-986.

47 Hetz C, Thielen P, Matus S, Nassif M, Court F, Kiffin R, Martinez G, Cuervo AM, Brown RH, Glimcher LH: XBP-1 deficiency in the nervous system protects against amyotrophic lateral sclerosis by increasing autophagy. Genes Dev 2009;23:2294-2306.

48 Henis-Korenblit S, Zhang P, Hansen M, McCormick M, Lee SJ, Cary M, Kenyon C: Insulin/IGF-1 signaling mutants reprogram ER stress response regulators to promote longevity. Proc Natl Acad Sci USA 2010;107: 9730-9735.

49 Koh EH, Park JY, Park HS, Jeon MJ, Ryu JW, Kim M, Kim SY, Kim MS, Kim SW, Park IS, Youn JH, Lee KU: Essential role of mitochondrial function in adiponectin synthesis in adipocytes. Diabetes 2007;56:2973-2981. 